Article

\title{
Ecotypic Morphological and Physio-Biochemical Responses of Two Differentially Adapted Forage Grasses, Cenchrus ciliaris L. and Cyperus arenarius Retz. to Drought Stress
}

\author{
Muhammad Adeel Ghafar ${ }^{1}$, Nudrat Aisha Akram ${ }^{1, *}$, Muhammad Hamzah Saleem ${ }^{2}$, Jianyong Wang ${ }^{3}$, \\ Leonard Wijaya ${ }^{4}$ and Mohammed Nasser Alyemeni ${ }^{4}$ \\ 1 Department of Botany, Government College University, Allama Iqbal Road, Faisalabad 38000, Pakistan; \\ madeelghafar@gmail.com \\ 2 College of Plant Science and Technology, Huazhong Agricultural University, Wuhan 430070, China; \\ saleemhamza312@webmail.hzau.edu.cn \\ 3 The Institute of Grassland Science, School of Life Science, Northeast Normal University, \\ Changchun 130024, China; wangy886@nenu.edu.cn \\ 4 Department of Botany and Microbiology, College of Science, King Saud University, \\ Riyadh 11451, Saudi Arabia; leon077@gmail.com (L.W.); mnyemeni@ksu.edu.sa (M.N.A.) \\ * Correspondence: nudrataauaf@yahoo.com
}

Citation: Ghafar, M.A.; Akram, N.A.; Saleem, M.H.; Wang, J.; Wijaya, L.; Alyemeni, M.N. Ecotypic Morphological and PhysioBiochemical Responses of Two Differentially Adapted Forage Grasses, Cenchrus ciliaris L. and Cyperus arenarius Retz. to Drought Stress. Sustainability 2021, 13, 8069. https://doi.org/10.3390/su13148069

Academic Editors: Lindsay Hutley and Pablo Peri

Received: 23 February 2021

Accepted: 17 May 2021

Published: 20 July 2021

Publisher's Note: MDPI stays neutral with regard to jurisdictional claims in published maps and institutional affiliations.

Copyright: (C) 2021 by the authors Licensee MDPI, Basel, Switzerland. This article is an open access article distributed under the terms and conditions of the Creative Commons Attribution (CC BY) license (https:/ / creativecommons.org/licenses/by/ $4.0 /)$.

\begin{abstract}
Crop performance and yield are the results of genotypic expression as modulated by continuous interaction with the environment. Among the environmental aspects, drought and salinity are the most important factors, which limit the forages, including grasses, on a global basis. Grass species have the ability to grow under low water conditions and can produce high dry yield, proteins, and energy in areas exposed to drought stress. For this purpose, we conducted the present study to understand the response of forage grasses under drought stress from two different regions (Salt Range and Faisalabad) of Punjab, Pakistan. Two ecotypes of each grass species (Cenchrus ciliaris L. and Cyperus arenarius Retz.) were grown in pots at the botanical research area, Government College University Faisalabad, Pakistan. A group of plants were subjected to drought stress $(60 \%$ field capacity) and controlled (100\% field capacity) after three weeks of seed germination. The results from the present study depicted that the fresh and dry weights of root and shoot were decreased significantly under drought conditions. Moreover, C. ciliaris of the Salt Range area showed more resistance and higher growth production under drought stress. The chlorophyll ( $a$ and $b$ ) contents were also decreased significantly, while MDA, total soluble sugars, and proline levels were increased significantly under water-limited environments in the $C$. arenarius of Salt Range area. Enzymatic antioxidants (superoxidase dismutase (SOD) and peroxidase (POD)) and leaf $\mathrm{Na}^{+}$were significantly raised in $C$. arenarius under drought stress collected from the Faisalabad region. Cenchrus ciliaris showed higher level of $\mathrm{H}_{2} \mathrm{O}_{2}$, total soluble proteins, glycinebetaine, catalase (CAT) and POD compared to $C$. arenarius. It also retained more leaf and root $\mathrm{Ca}^{2+}$, and root $\mathrm{K}^{+}$under drought stress. It was concluded from the study that $C$. ciliaris is more resistant to drought in biomass production collected from the Salt Range area. The results suggested that $C$. ciliaris can be more widely used as a forage grass under water-scarce conditions as compared to C. arenarius.
\end{abstract}

Keywords: drought; halophytes; reactive oxygen species; forages; osmolytes

\section{Introduction}

Fresh water constitutes not more than $2.5 \%$ of total water on the planet, only $0.6 \%$ of which is available as a usable source of water for agriculture, industry, and as potable water sources, with the remainder stored in ice sheets, glaciers, and snow [1,2]. Many areas of crop production in developing countries such as Pakistan are located in semi-arid areas, where drought accounts for large harvest losses and thus threatens the sustainability of the agricultural industry [3]. Plants are typically exposed to a broad myriad of biotic and abiotic 
stresses, including feeding from wild animals and insects, weed infestation, mechanical injury, diseases, low soil fertility, drought, salinity, and others that can diminish the plant photosynthetic area, and thus the attained total plant biomass or grain yield [4-6]. Water deficiency-induced impairment in photosynthesis is attributed to damage composition of thylakoid membranes in chloroplasts because the lipid contents of cell membranes are susceptible to the reactive oxygen species (ROS) produced as a consequence of drought $[7,8]$. Stress conditions can disturb the dynamic equilibrium of ROS production which promotes oxidative stress, membrane lipid peroxidation, and disrupts the structure and function of the cell membrane system $[9,10]$. It was reported that drought stress can increase lipid peroxidation and MDA, an oxidized product of membrane lipids, indicating the prevalence of oxidative stress and membrane damage [11,12]. Environmental stress can trigger the ROS production in plants, which results in oxidative damage. However, plants possess an efficient antioxidative defense system to detoxify the ROS generation [13]. Additionally, drought conditions reduce the photosynthetic rate, expansion of leaves, stomatal closure, the levels of ROS, and decrease translocation within the plant, resulting in decreased crop yields [7,14-16]. Most of the halophytes have adapted $C_{4}$ and CAM mechanisms of carbon fixation for water conservation and accumulate assimilates effectively [17]. The rate of photosynthesis decreases in many fodder grasses under drought stress, i.e., Festuca pratensis, Lolium perenne, Dactylis glomerata, Phleum pretense and Arrhenatherum elatius [2].

The survival of plants and production of the agricultural yield under stressful environment depend on the plant resistance. It depends on three basic elements: properties of the organism, which determine the vulnerability or strength of its structures to stress; the organism's ability to withstand damage; and adaptation or acclimatization [18,19]. Tall fescue (Festuca arundinacea) is a popular forage grass which can tolerate and adjust osmotic level for desiccation tolerance as well as avoidance. It also develops an efficient root system in soil to use maximum soil moisture effectively [20]. Plants develop phenological adaptations for stress tolerance, e.g., when enough rainwater or water is available, to complete their life cycle over short durations (weeks to months) [21]. Perennial grasses show temporary dormancy of buds and meristems under prolonged drought stress [22]. Most of the forage grasses are drought-tolerant and have adapted various physiological mechanisms to survive under low water conditions [23]. Moreover, under drought stress, grasses accumulate various osmolytes for osmotic adjustment and osmoprotection. These osmoprotectants accumulate in water stressed cells and stimulate functioning of normal metabolites [15]. These osmoprotectants include proline, glycinebetaine, sugars and phenolics.

Across the sub-continent of Pakistan, the Salt Range and coastal areas are exposed to high salinity and drought conditions. Halopyrum mucronatum and Cenchrus ciliaris have been examined for their drought tolerance and showed long term desiccation tolerance and survival [24]. C. ciliaris is used as fodder grass for livestock in arid and semi-arid regions [25]. It was also reported that some of the responses to salinity and drought by these species are the same, i.e., osmotic adjustment, relative water contents, and dry mass accumulation. Forage grasses have salinity and drought tolerance due to similar earlier responses to stress [26]. In the present study, C. ciliaris and C. arenarius Retz. were subjected to drought stress ( $60 \%$ field capacity) to determine their physio-biochemical responses, i.e., oxidative defense mechanism, osmolyte production, growth parameters and ionic balance in response to drought stress. In this study, we examined (i) morpho-physiological traits and photosynthetic capacity, (ii) oxidative stress and response of antioxidant enzymes and nutrient uptake in plant organs of forage grasses collected from various ecotypic regions of Salt Range areas subjected to controlled and drought conditions.

\section{Materials and Methods}

\subsection{Plant Material and Growth Condition}

Two grass species, Cenchrus ciliaris L. and Cyperus arenarius Retz., were collected from the salt-affected soils from the surroundings of Khewra Salt Mines, Pind Dadan Khan, Salt Range, Punjab, Pakistan during May 2018. The analyses of soil observed ECe, $19.92 \mathrm{dS} \mathrm{m}^{-1}$ 
and $\mathrm{pH}, 6.62$. Similarly, the ecotypes of both grasses were also collected from a normal, non-saline habitat within the Faisalabad region. The different physiochemical properties of the soil of this region indicated ECe, $1.82 \mathrm{dS} \mathrm{m}^{-1}$, and $\mathrm{pH}$ 8.20. These species were considered as the control (non-saline). Plants of both populations of C. ciliaris and C. arenarius were grown in normal non-saline soil for a period of three months in the Research Area, Government College University Faisalabad, Pakistan. The plastic pots $(22.5 \mathrm{~cm}$ in diameter) filled with soil (loam and sand in equal quantities) were used for growing plants of both populations. The plants were kept under full sunlight and irrigated daily with good-quality irrigation water until their establishment under the climatic conditions of Faisalabad region.

Grass plugs of uniform size (rhizomes of 3 inches in height) were transplanted on 4 August 2018 into plastic pots filled with $8 \mathrm{~kg}$ loamy soil ( $\mathrm{pH}=7.4, \mathrm{ECe}=5.2 \mathrm{dS} \mathrm{m}^{-1}$, and $\mathrm{Na}^{+}, \mathrm{K}^{+}$and $\mathrm{Ca}^{2+}$ contents were $13.0,28.3$ and 11.0 meq $\mathrm{L}^{-1}$, respectively) in a completely randomized design with four replicates. All pots were irrigated at three-day intervals, and plants were allowed to establish for 48 days before the start of water-deficit treatments. Plants were clipped at $3 \mathrm{~cm}$ height, to maintain uniform plant size. The water stress was applied on the basis of soil field capacity by maintaining the calculated level of moisture percentage following Akram et al. [27]. Two water levels (100\% and $60 \%$ field capacity) were applied in this study. After six weeks of drought stress treatments, data were collected for the following growth and physio-biochemical attributes which are described below:

\subsection{Plant Biomass}

After harvesting, the fresh weights of shoots and roots of four plants per treatments were determined by oven drying at $70{ }^{\circ} \mathrm{C}$ for $72 \mathrm{~h}$ with dry weight recorded. Length of shoots and the longest root extension were also measured by using measuring scale.

\subsection{Chlorophyll Contents}

Leaf chlorophyll contents were determined by using a method proposed by Arnon [28]. Fresh leaf $(0.5 \mathrm{~g})$ of each plant was extracted in $10 \mathrm{~mL} \mathrm{80 \%}(v / v)$ acetone. The samples were placed overnight at $4{ }^{\circ} \mathrm{C}$. All extracts were centrifuged at 10,000 rpm for $5 \mathrm{~min}$ and supernatant was collected. Then, the absorbance of supernatant was taken at 645 and $663 \mathrm{~nm}$ using a UV-visible spectrophotometer and chlorophyll $a$ and $b$ contents were calculated.

\subsection{Ascorbic Acid}

Mukherjee and Choudhuri [29] proposed a method for the estimation of ascorbic acid. A fresh leaf $(0.25 \mathrm{~g})$ was homogenized in trichloroacetic acid $(10 \mathrm{~mL} ; 6 \%)$. Each $4 \mathrm{~mL}$ of the extract was mixed with $2 \mathrm{~mL}$ of dinitrophenyl hydrazine. One drop of $10 \%$ thiourea was added and the mixture was boiled at room temperature. Afterwards, $5 \mathrm{~mL}$ of $80 \%(v / v)$ $\mathrm{H}_{2} \mathrm{SO}_{4}$ was added to the mixture. The absorbance of the sample was recorded at $530 \mathrm{~nm}$.

\subsection{Glycinebetaine (GB) Contents}

Leaf glycinebetaine contents were quantified following a method proposed by Grieve and Grattan [30]. They took $1.0 \mathrm{~g}$ fresh leaf and simultaneously grinded in $10 \mathrm{~mL}$ solution of $0.5 \%$ toluene and filtered it. Then, $1.0 \mathrm{~mL}$ filtrate was taken in the test tube and mixed with $1 \mathrm{~mL}$ of $2 \mathrm{~N} \mathrm{H}_{2} \mathrm{SO}_{4}$. After this, $0.5 \mathrm{~mL}$ of supernatant was added to $0.2 \mathrm{~mL}$ of potassium tri-iodide, the mixture was shaken, and it was cooled in an ice bath for $90 \mathrm{~min}$. The icecooled distilled water $\left(2.8 \mathrm{~mL}\right.$ ) along with $6 \mathrm{~mL}$ of 1,2 dichloroethane (cooled at $-10^{\circ} \mathrm{C}$ ) was poured into the sample containing test tubes. Two layers were formed in the test tubes by passing the stream of air for $2 \mathrm{~min}$; during this process, the tubes were maintained in an ice bath. The reaction was completed, the organic aqueous layer was separated, and its optical density was measured at $365 \mathrm{~nm}$ using a spectrophotometer. 


\subsection{Proline Contents}

Quantification of free proline content was determined using the method of Bates et al. [31]. Fresh leaf $(0.5 \mathrm{~g})$ was extracted in $10 \mathrm{~mL}$ of freshly prepared $3 \%(w / v)$ sulfosalicylic acid. The homogenate was filtered and mixed with an equal volume of acid ninhydrin and boiled for $1 \mathrm{~h}$ at $100{ }^{\circ} \mathrm{C}$. The reaction mixture was cooled in an ice bath. Then, toluene $(5 \mathrm{~mL})$ was added to the reaction mixture in each test tube. After vortexing the mixture for one minute, two layers were formed. The chromophore containing toluene was removed and absorbance was recorded at $520 \mathrm{~nm}$.

\subsection{Malondialdehyde (MDA)}

Cakmak and Horst [32] proposed a method for the estimation of malondialdehyde contents in leaf samples. Fresh leaf $(0.5 \mathrm{~g})$ was homogenized in $5 \mathrm{~mL}$ of TCA $(5 \% w / v)$ and centrifuged at $12,000 \mathrm{rpm}$ for $15 \mathrm{~min}$. Equal volume of supernatant and TBA $(0.5 \%$ in $20 \%$ w/v TCA) were mixed. The mixture was boiled at $100{ }^{\circ} \mathrm{C}$ for $25 \mathrm{~min}$. Then, the OD was recorded at $532 \mathrm{~nm}$ and $600 \mathrm{~nm}$ and the MDA contents were calculated.

\subsection{Total Phenolics}

A method proposed by Julkenen-Titto [33] was used to determine the total phenolic contents in the extract. Fresh leaf $(0.1 \mathrm{~g})$ was homogenized in $5 \mathrm{~mL}$ acetone $(80 \%)$. The samples were centrifuged at $10,000 \times g$ for $10 \mathrm{~min}$. Then, $100 \mu \mathrm{L}$ of supernatant, $2 \mathrm{~mL}$ of $\mathrm{dH}_{2} \mathrm{O}, 1 \mathrm{~mL}$ of Folin-Phenol Ciocalteu's reagent, and $5 \mathrm{~mL}$ of $20 \%$ sodium carbonate were mixed. The volume was made up to $10 \mathrm{~mL}$ with distilled water. Then, total phenolics in leaf tissues were estimated at $750 \mathrm{~nm}$.

\subsection{Total Soluble Proteins}

The Bradford [34] method was used to determine the total soluble proteins contents in the leaf extract. Fresh leaf $(0.5 \mathrm{~g})$ was extracted in $5 \mathrm{~mL}$ of $50 \mathrm{mM}$ potassium phosphate buffer ( $\mathrm{pH} 7.8$ ) and prepared in an ice bath. The extract was centrifuged at $10,000 \times g$ for 15 min at $4{ }^{\circ} \mathrm{C}$.

\subsection{Total Soluble Sugars}

A method proposed by Yemm and Willis [35] was used to determine the total soluble sugars. A leaf $(0.1 \mathrm{~g})$ was extracted in $10 \mathrm{~mL}$ of $80 \%$ ethanol. The supernatant $(0.1 \mathrm{~mL})$ was mixed with $3 \mathrm{~mL}$ of anthrone reagent in a test tube. The reaction mixture was boiled for $10 \mathrm{~min}$ and then cooled at room temperature. The total soluble sugars were determined at $630 \mathrm{~nm}$ against glucose curve.

\subsection{Hydrogen Peroxide $\left(\mathrm{H}_{2} \mathrm{O}_{2}\right)$ Contents}

Hydrogen peroxide contents were determined following the method of Velikova et al. [36]. Fresh leaf $(0.5 \mathrm{~g})$ was extracted in an ice bath with $5 \mathrm{~mL}(0.1 \% ; w / v)$ trichloroacetic acid. The extract was centrifuged at $12,000 \times g$ for $15 \mathrm{~min}$, and $0.5 \mathrm{~mL}$ of the extract was added to $0.5 \mathrm{~mL}$ of $10 \mathrm{mM}$ potassium phosphate buffer $(\mathrm{pH}, 7.0)$ and $1 \mathrm{~mL}$ of $1 \mathrm{M}$ potassium iodide. The absorbance of the supernatant was read at $390 \mathrm{~nm}$.

\subsection{Activity of Superoxide Dismutase (SOD)}

Following the method of Giannopolitis and Ries [37], the activity of SOD enzymes was determined. The reaction mixture contained distilled $\mathrm{H}_{2} \mathrm{O}$, phosphate buffer, Lmethionine, triton- $X$, nitroblue tetrazolium, enzyme extract, and riboflavin. The absorbance was measured at $560 \mathrm{~nm}$ for the calculations of the activity of the SOD enzyme.

\subsection{Activity of Catalase (CAT) Enzyme}

Following the method devised by Chance and Maehly [38], the enzyme extract $(0.1 \mathrm{~mL})$ was mixed with $1.9 \mathrm{~mL}$ potassium phosphate buffer and $1 \mathrm{~mL}$ of $\mathrm{H}_{2} \mathrm{O}_{2}(5.9 \mathrm{mM})$. Then, the absorbance of the reaction mixture was measured at $240 \mathrm{~nm}$. 


\subsection{Activity of Peroxidase (POD) Enzyme}

A method proposed by Chance and Maehly [38] was used to determine the activity of the POD enzyme. The enzyme extract $(50 \mu \mathrm{L})$ added to $100 \mu \mathrm{L}$ of $\mathrm{H}_{2} \mathrm{O}_{2}(40 \mathrm{mM})$ in a cuvette. Afterwards, $100 \mu \mathrm{L}$ of guaicol $(20 \mathrm{mM})$ and $750 \mu \mathrm{L}$ of potassium phosphate buffer were mixed, and the absorbance was noted at $470 \mathrm{~nm}$.

\subsection{Analyses of Mineral Nutrients}

Dried ground shoot and root $(0.1 \mathrm{~g})$ were taken in a digestion flask and $2 \mathrm{~mL}$ of the digestion mixture was prepared and added into each sample, according to Wolf [39]. The samples were incubated overnight, then the flasks were heated at $150{ }^{\circ} \mathrm{C}$ and $1 \mathrm{~mL} \mathrm{H}_{2} \mathrm{O}_{2}$ $(35 \%)$ was poured into it. The mixture was heated until the reaction mixture became clear. After cooling, the volume was maintained up to $50 \mathrm{~mL}$ using distilled water. The extract was filtered gently and used for the determination of $\mathrm{Na}^{+}, \mathrm{K}^{+}$and $\mathrm{Ca}^{2+}$.

\subsection{Determination of $\mathrm{Na}^{+}, \mathrm{K}^{+}$and $\mathrm{Ca}^{2+}$}

Different concentrations of standards for sodium $\left(\mathrm{Na}^{+}\right)$, potassium $\left(\mathrm{K}^{+}\right)$and calcium $\left(\mathrm{Ca}^{2+}\right)$ were prepared. The standard curves of these ions were established by using a flame photometer. After standardization of the equipment, the filtrated samples were run on the flame photometer for the determination of subjected ions.

\subsection{Statistical Analysis}

The obtained data were subjected to analysis of variance (ANOVA) by using COSTAT software [40], and least significance difference was determined at a 5\% probability level. Graphical presentation was carried out using Origin-2017 software. RStudio was used to illustrate the correlation and principal component analysis.

\section{Results}

\subsection{Growth Parameters}

Shoot fresh and dry weights of both grass species, C. ciliaris and C. arenarius, were reduced significantly $(p \leq 0.001)$ under drought stress conditions. The response of both species to drought stress was significantly $(p \leq 0.001)$ different from each other. However, the ecotypic response was non-significant in this parameter. The $C$. ciliaris of Salt Range showed the highest biomass production under control and drought conditions (Figure 1). The root biomass was also reduced significantly under water stress, and C. arenarius was the most impacted species by drought stress (Figure 1). Shoot length was reduced significantly $(p \leq 0.01)$ under low water availability. Ecotype-affected root growth of $C$. ciliaris of the Salt Range area significantly $(p \leq 0.05)$ showed maximum root length under drought stress. The response of halophytic species of both ecotypes was significant (Figure 1).

\subsection{Chlorophyll Pigments}

Chlorophyll $a$ and $b$ contents were decreased due to moisture stress in both halophytic species (Figure 2) of Faisalabad and Salt Range areas. It was observed from the results that $C$. ciliaris of Salt Range had the highest leaf chlorophyll a pigment. Drought stress significantly $(p \leq 0.001)$ reduced the chlorophyll contents of $C$. arenarius of Faisalabad region (Figure 2). It was observed that $C$. ciliaris contained more chlorophyll $b$ content than $C$. arenarius in both ecotypes. Most strikingly, drought stress reduced chlorophyll $b$ content of $C$. arenarius of Salt Range (Figure 2). Total chlorophyll contents were also decreased significantly $(p \leq 0.01)$ due to the low level of water availability. Results showed that ecotypic variation and response of species were non-significant for this parameter. $C$. ciliaris had the highest total chlorophyll concentration (Figure 2). Chlorophyll ratio was non-responsive in this attribute (Figure 2). 

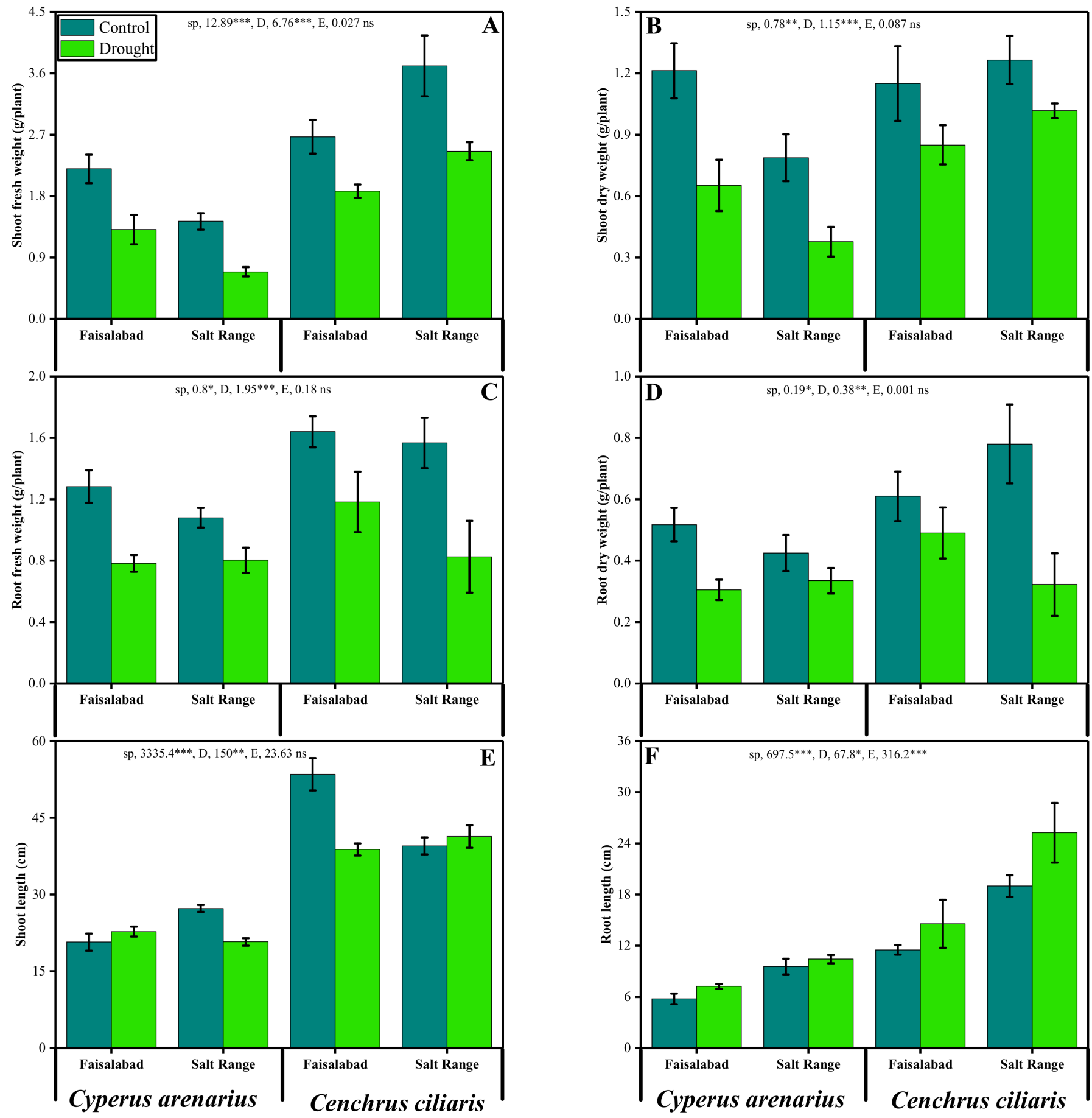

Figure 1. Shoot fresh weight (A), shoot dry weight (B), root fresh weight (C), root dry weight (D), shoot length (E), and root length (F) of grass species (Cenchrus ciliaris L. and Cyperus arenarius Retz.) of two different ecotypes (Faisalabad and Salt Range) grown under control (normal watering) and drought (60\% field capacity) stress. Bars sharing different letter(s) for each parameter are significantly different from each other according to Duncan's multiple range test $(p<0.05)$. All the data represent the averages of four replications $(n=4)$. Error bars represent the standard deviation (SD) of four replicates. Different abbreviations used in the figure are: Sp, Species; E, Ecotypes; D, Drought; ns, non-significant; ${ }^{*}{ }^{* *}$ and ***, significant at $0.05,0.01$ and 0.001 levels, respectively. 

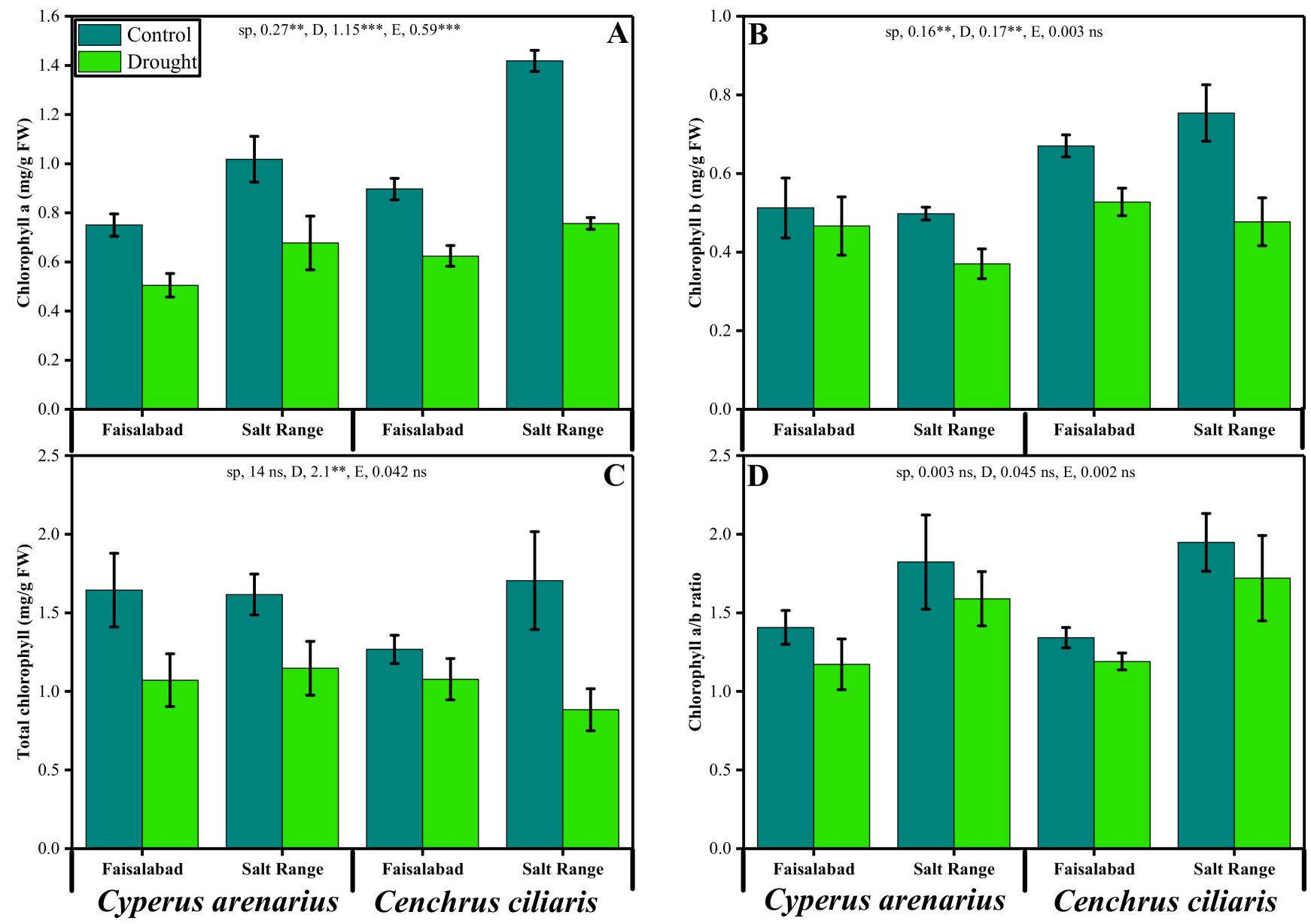

Figure 2. Chlorophyll $a$ (A), chlorophyll $b$ (B), total chlorophyll (C), and chlorophyll $a / b(\mathbf{D})$ of grass species (Cenchrus ciliaris L. and Cyperus arenarius Retz.) of two different ecotypes (Faisalabad and Salt Range) grown under control (normal watering) and drought (60\% field capacity) stress. Bars sharing different letter(s) for each parameter are significantly different from each other according to Duncan's multiple range test $(p<0.05)$. All the data represent the average of four replications $(n=4)$. Error bars represent the standard deviation (SD) of four replicates. Different abbreviations used in the figure are: Sp, Species; E, Ecotypes; D, Drought; ns, non-significant; ${ }^{* *}$ and ${ }^{* * *}$, significant at 0.01 and 0.001 levels, respectively.

\subsection{Total Phenolics, Ascorbic Acid and Malondialdehyde}

Data analysis showed that phenolic contents were significantly $(p \leq 0.01)$ higher than the control in response to drought stress in both halophytic species. Results showed that C. arenarius of the Salt Range improved remarkably under drought stress. Ascorbic acid (AsA) concentration was improved significantly $(p \leq 0.01)$ to cope with drought-induced constraints. The highest level of AsA was observed in C. arenarius from both ecotypic sites (Figure 3). Our results also show that $C$. arenarius was more resistant to water-deficit environments, when compared to the $C$. ciliaris. Malondialdehyde is an indicator of lipid peroxidation under drought; therefore, it was found that MDA contents increased under drought stress in both species (Figure 3). It was observed that $C$. arenarius showed a high level of MDA, which is an indicator of more lipid peroxidation in membranes of this species.

\subsection{Osmoprotectants}

Analysis of variance showed that water stress improved glycinebetaine (GB) contents significantly of both halophytic species. Ecotypic variation of both areas was also significant $(p \leq 0.01)$ in terms of GB contents (Figure 3). It was also observed that $C$. ciliaris improved maximum GB contents than the other. Analysis of variance showed that proline contents 
improved significantly $(p \leq 0.001)$ in both halophytic species under $60 \%$ field capacity (Figure 3). Ecotypic variations also significantly $(p \leq 0.001)$ improved the proline contents to cope with detrimental effects of drought. It was inferred from the data that $C$. arenarius of Salt Range accumulated maximum proline contents, compared to $C$. ciliaris. Level of total soluble sugars was also improved significantly $(p \leq 0.01)$ under water stress conditions. Ecotypic variations were non-responsive in this parameter (Figure 3). Both halophytic species improved their total soluble sugar contents under drought stress.
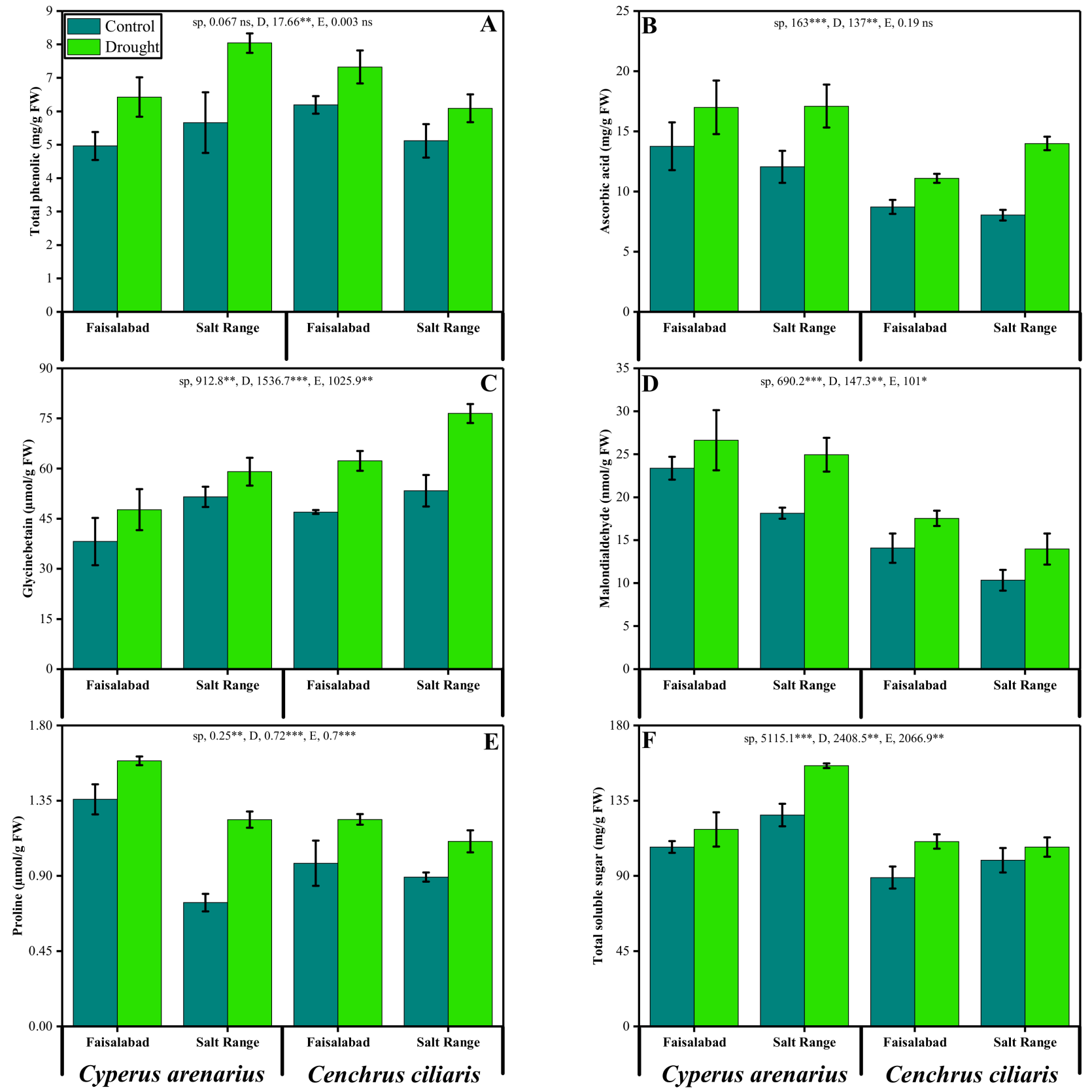

Figure 3. Total phenolics (A), ascorbic acid (B), glycinebetaine (C), malondialdehyde (D), proline (E), and total soluble sugar (F) of forage grass species (Cenchrus ciliaris L. and Cyperus arenarius Retz.) of two different ecotypes (Faisalabad and Salt Range) grown under control (normal watering) and drought (60\% field capacity) stress. Bars sharing different letter (s) for each parameter are significantly different from each other according to Duncan's multiple range test $(p<0.05)$. All the data represent the average of four replications $(n=4)$. Error bars represent standard deviation (SD) of four replicates. Different abbreviations used in the figure are: Sp, Species; E, Ecotypes; D, Drought; ns, non-significant; *,** and ${ }^{* * *}$, significant at 0.05 , 0.01 and 0.001 levels, respectively. 


\subsection{Hydrogen Peroxide and Total Soluble Proteins}

The level of hydrogen peroxide $\left(\mathrm{H}_{2} \mathrm{O}_{2}\right)$ was increased significantly $(p \leq 0.001)$ under drought stress conditions (Figure 4). It was also observed that both plant species showed elevated level of $\mathrm{H}_{2} \mathrm{O}_{2}$ under water-deficient conditions. It was observed that $C$. ciliaris of the Salt Range showed the highest level of hydrogen peroxide $\left(\mathrm{H}_{2} \mathrm{O}_{2}\right)$ contents under drought conditions (Figure 4). Data showed that drought improved the total soluble protein contents significantly $(p \leq 0.001)$ in both grass species. Both species of halophytes were also significantly $(p \leq 0.001)$ responsive to drought in this parameter (Figure 4$)$. Results showed that $C$. ciliaris of the Salt Range contained the highest level of total soluble proteins (TSP) contents under drought conditions (Figure 4).
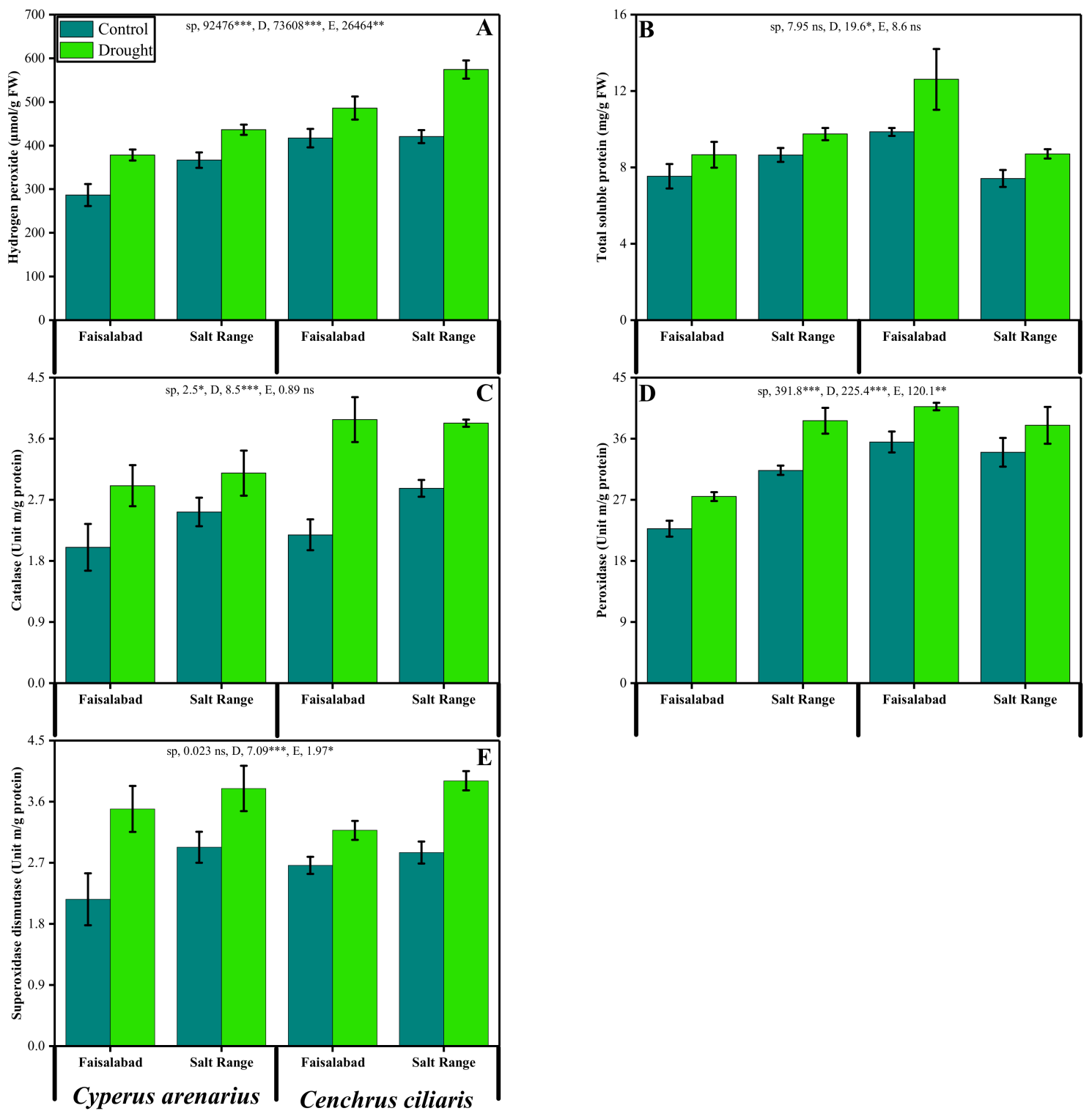

Figure 4. Hydrogen peroxide (A), total soluble protein (B), catalase (C), peroxidase (D), and superoxide dismutase (E) activities of forage grass species (Cenchrus ciliaris L. and Cyperus arenarius Retz.) of two different ecotypes (Faisalabad and Salt Range) grown under control (normal watering) and drought (60\% field capacity) stress. Bars sharing different letter(s) for each parameter are significantly different from each other according to Duncan's multiple range test $(p<0.05)$. All the data represent the average of four replications $(n=4)$. Error bars represent the standard deviation (SD) of four replicates. Different abbreviations used in the figure are: Sp, Species; E, Ecotypes; D, Drought; ns, non-significant; ${ }^{*}{ }^{* *}$ and ***, significant at $0.05,0.01$ and 0.001 levels, respectively. 


\subsection{Activities of Enzymatic Antioxidants}

Data analysis showed that the activity of catalase (CAT) was improved significantly $(p \leq 0.001)$ under drought stress in both species of halophytes (Figure 4). Highest activity of catalase enzyme was observed in C. ciliaris of both ecotypes under drought stress (Figure 4). The activity of superoxide dismutase (SOD) was also increased under stress conditions and helped plants to cope with detrimental radicals produced under stress conditions. Highest activity of SOD enzyme was observed in C. arenarius of Faisalabad region and C. ciliaris of the Salt Range (Figure 4). Analysis of variance showed that the activity of peroxidase (POD) enzyme was improved significantly $(p \leq 0.001)$ under water-deficient conditions to cope with harmful effects of ROS. Both grass species and ecotypic variations were significantly varied in the defensive activity of POD enzyme under water stress. It was also observed that $C$. arenarius of the Salt Range exhibited the maximum activity of POD enzyme under drought stress (Figure 4).

\subsection{Nutrient Uptake}

Results showed that levels of $\mathrm{Na}^{+}$increased in roots and leaves under drought stress (Figure 5). It was observed that Cyperus arenarius of the Faisalabad region showed a greater increase in $\mathrm{Na}^{+}$under water stress conditions. Ecotypes responded significantly to drought stress in this parameter. The results from the present study also show that the concentration of $\mathrm{K}^{+}$in the leaves and roots declined when plants were exposed to the water-deficit environment. Cenchrus ciliaris of the Salt Range was resistant to change in $\mathrm{K}^{+}$ concentrations of the leaf (Figure 5). However, the ecotypic response was non-significant for this parameter. Analysis of variance showed that the concentration of leaf and root $\mathrm{Ca}^{2+}$ significantly decreased under water stress conditions in both $C$. arenarius and $C$. ciliaris forage grasses. It was observed that the concentration of $\mathrm{K}^{+}$was highly decreased in $C$. arenarius of the Faisalabad region (Figure 5).

\subsection{Correlation Analysis}

A correlation analysis of two grass species was also illustrated to study the relationship between various parameters studied in this experiment (Figure 6). In both species, $\mathrm{Na}$ contents in the roots were positively correlated with $\mathrm{Na}$ contents in the shoots, while being negatively correlated with $\mathrm{Ca}$ and $\mathrm{K}$ contents in the roots and shoots of the plants. In addition, Na contents (roots and shoots) were also positively correlated with antioxidant capacity, oxidative stress indicators, sugars, and phytohormones, while negatively correlated with plant growth and biomass and photosynthetic measurements. In contrast, $\mathrm{Ca}$ and $\mathrm{K}$ contents in the roots and shoots were positively correlated with plant growth and biomass and photosynthetic measurements, while negatively correlated with the antioxidant capacity, oxidative stress indicators, sugars, and phytohormones. This correlation analysis showed a close connection between growth and nutrient uptake by the plants.

\subsection{Principal Component Analysis}

A principal component analysis (PCA) was also constructed to illustrate the effect of different levels of drought in both grass species and is presented in Figure 7. In C. ciliaris, total components exhibited more than $94 \%$ of the database, while $C$. arenarius accounted for more than $92 \%$ of the total database. In addition, Dim-1 accounted for $61.9 \%$, and Dim-2 accounted for $32.1 \%$ of the database in C. ciliaris, while Dim- 1 accounted for $69 \%$ and Dim-2 accounted for $23.5 \%$ of the database in C. arenarius. In both grass species, oxidative stress indicators, Na contents in the roots and shoots, glycine betaine content, antioxidant capacity, total soluble sugar, proline content and phenolic contents showed a positive correlation, while $\mathrm{Ca}$ and $\mathrm{K}$ contents, plant growth parameters, and photosynthetic measurements showed a negative correlation among all different parameters in the database. 

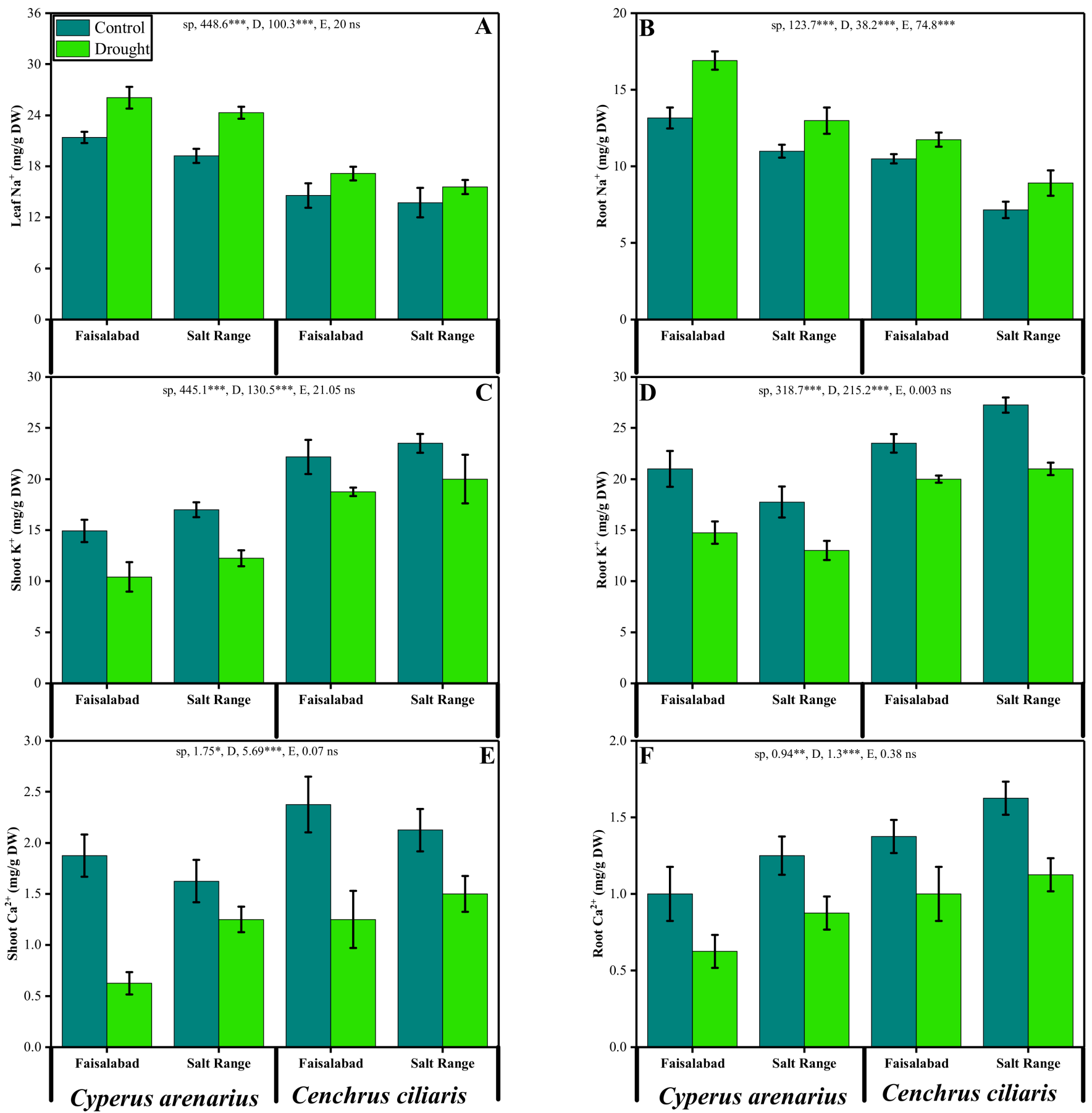

Figure 5. Shoot and root $\mathrm{Na}^{+}(\mathbf{A}, \mathbf{B}), \mathrm{K}^{+}(\mathbf{C}, \mathbf{D})$, and $\mathrm{Ca}^{2+}(\mathbf{E}, \mathbf{F})$ concentrations of forage grass species (Cenchrus ciliaris L. and Cyperus arenarius Retz.) of two different ecotypes (Faisalabad and Salt Range) grown under control (normal watering) and drought (60\% field capacity) stress. Bars sharing different letter(s) for each parameter are significantly different from each other according to Duncan's multiple range test $(p<0.05)$. All the data represent the average of four replications $(n=4)$. Error bars represent the standard deviation (SD) of four replicates. Different abbreviations used in the figure are: Sp, Species; E, Ecotypes; D, Drought; ns, non-significant; ${ }^{*}{ }^{* *}$ and ${ }^{* * *}$, significant at $0.05,0.01$ and 0.001 levels, respectively. 


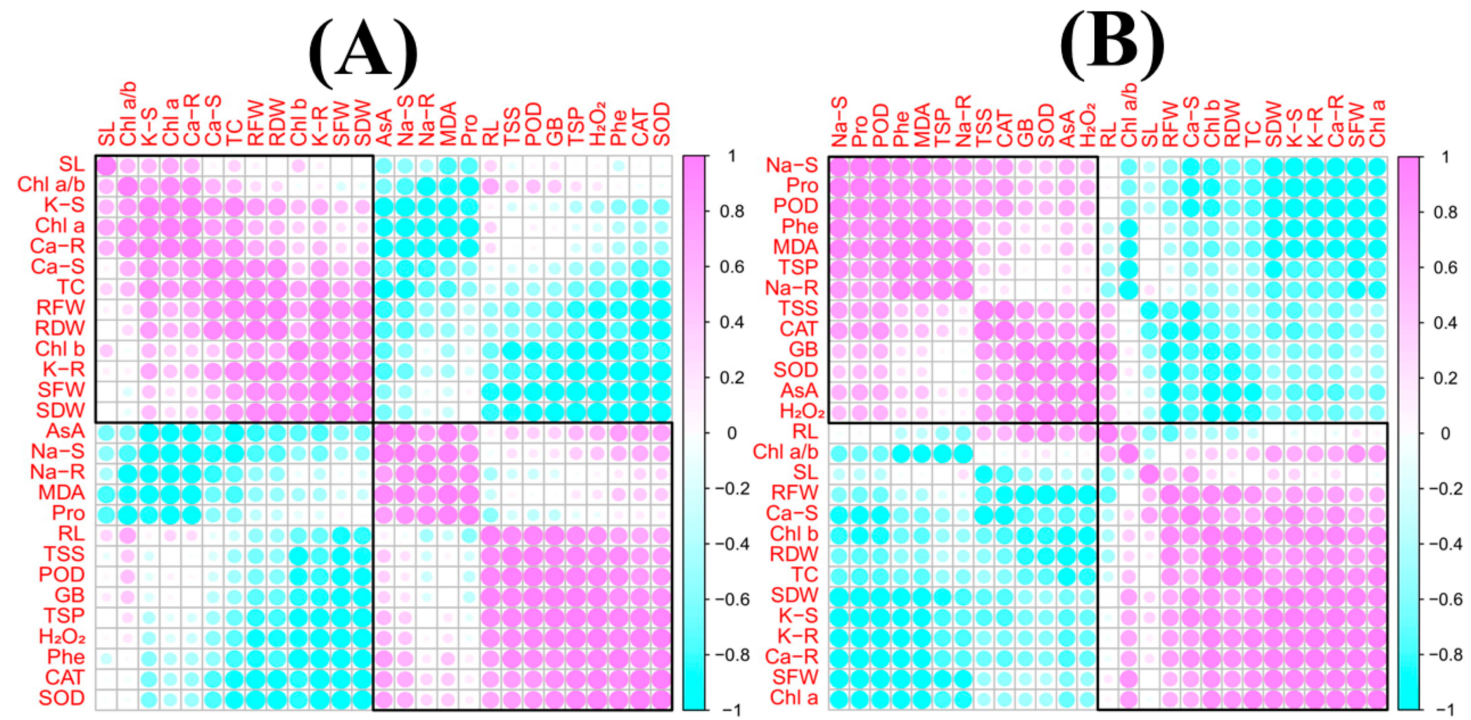

Figure 6. Pearson's correlation analysis in two grass species, C. ciliaris (A) and C. arenarius (B), using different morphophysio-biochemical attributes. Different abbreviations used in this figure are as follows: SL (shoot length), chl. $a / b$ (chlorophyll $a / b$ contents), K-S (potassium contents in the shoots), chl. $a$ (chlorophyll $a$ contents), Ca-R (calcium contents in the roots), Ca-S (calcium contents in the shoots), TC (total chlorophyll contents), RFW (root fresh weight), RDW (root dry weight), chl. $b$ (chlorophyll $b$ contents), K-R (potassium contents in the roots), SFW (shoot fresh weight), SDW (shoot dry weight), AsA (ascorbic acid content), Na-S (sodium content in the shoots), Na-R (sodium content in the roots), MDA (malondialdehyde content), Pro (proline content), RL (root length), TSS (total soluble sugar), POD (peroxidase activity), GB (glycinebetaine), TSP (total soluble proteins), $\mathrm{H}_{2} \mathrm{O}_{2}$ (hydrogen peroxide initiation), Phe (phenolic content), CAT (catalase activity) and SOD (superoxidase activity).

(A)

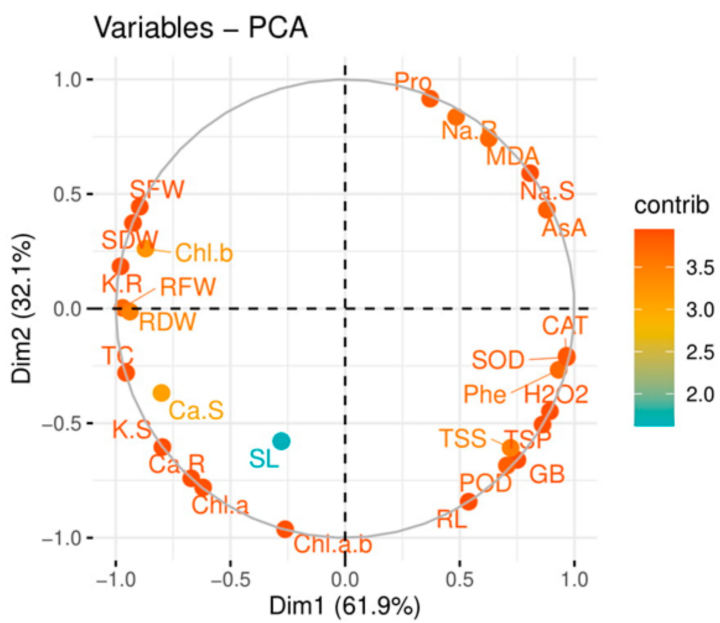

(B)

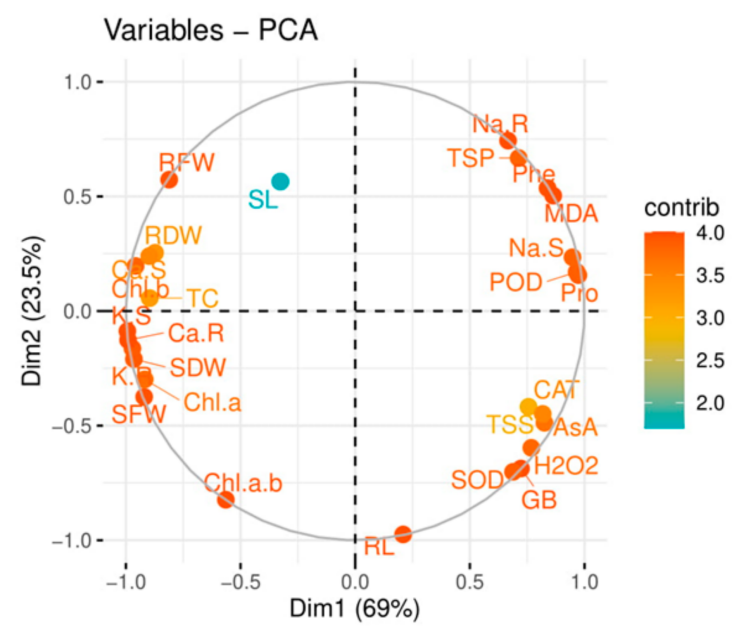

Figure 7. Principal component analysis of two grass species, C. ciliaris (A) and C. arenarius $(\mathbf{B})$, under controlled and drought stress conditions. Different abbreviations used in this figure are as follows: SL (shoot length), chl. $a / b$ (chlorophyll $a / b$ contents), K-S (potassium contents in the shoots), chl. $a$ (chlorophyll $a$ contents), Ca-R (calcium contents in the roots), Ca-S (calcium contents in the shoots), TC (total chlorophyll contents), RFW (root fresh weight), RDW (root dry weight), chl. $b$ (chlorophyll $b$ contents), K-R (potassium contents in the roots), SFW (shoot fresh weight), SDW (shoot dry weight), AsA (ascorbic acid content), Na-S (sodium content in the shoots), Na-R (sodium content in the roots), MDA (malondialdehyde content), Pro (proline content), RL (root length), TSS (total soluble sugar), POD (peroxidase activity), GB (glycine betaine), TSP (total soluble protein), $\mathrm{H}_{2} \mathrm{O}_{2}$ (hydrogen peroxide initiation), Phe (phenolic content), CAT (catalase activity) and SOD (superoxidase activity). 


\section{Discussion}

Due to their sessile nature, all plants are usually exposed to various abiotic stresses which affect their normal growth and physiological processes [18,19]. Water stress is one striking abiotic stress that lowers the turgor potential and leads to the induction of the stress response by closing the stomata and lowering the photosynthetic process [14]. Water stress induced secondary responses, i.e., production of enzymatic and non-enzymatic antioxidants, production of osmolytes, flavonoids, phytoalexins to cope with detrimental effects of drought by the up-regulation of oxidative defense mechanism and accumulation of osmolytes in the cell to maintain osmotic pressure [41]. Prolonged drought stress inhibited enzyme function and destroyed photosynthetic apparatus due to the high production of reactive oxygen species (ROS) in photosystems [42,43]. The level of chlorophyll contents in photosystems is an indication of normal functioning of photosynthetic processes and severely affected when subjected to water shortage. In agreement with these studies, our results showed that chlorophyll $a$ and $b$ contents were decreased due to moisture stress in both grass species of Faisalabad and Salt Range (Figure 2).

The most prominent finding was the effect of water stress reducing growth and seed germination [44]. As studied in alfalfa (Medicago sativa), water stress caused a reduction in the seed germination, hypocotyl length, and fresh and dry weights of alfalfa plants [45]. Drought-induced reduction in yield was reported in pearl millet [46], and maize [47], due to low water availability, closure of stomata, reduced efficiency of the Calvin cycle, and induction of secondary responses to cope with stress. Under drought stress, sunflower plants tended to complete their life cycle in a short span and decreased the number of grains and total weight [48]. Results of the current research showed that shoot fresh and dry biomass of both halophytic species were reduced by drought stress (Figure 1). Ecotypic response was non-significant in this parameter. The Cenchrus ciliaris of the Salt Range showed the highest biomass production under control and drought conditions (Figure 1). Root biomass was also reduced significantly under water stress. Shoot length was reduced significantly under low water availability (Figure 1). This reduction may be due to altered water relations, decline in $\mathrm{CO}_{2}$ assimilation rate, membrane damage of affected tissues, and oxidative stress in plants [44,49].

Gharibi et al. [50] showed that phenolic contents increased in achillea (Achillea pachycephalla) collected from different regions of Iran under water stress, which is in agreement with our results that showed that phenolic contents of $C$. arenarius and C. ciliaris halophytic species were increased under water stress conditions. Results showed that total phenolics of $C$. arenarius of the Salt Range remarkably decreased under drought stress (Figure 3). Sakr and El-Metwally [51] also reported that stress decreased the phenolic contents in many species of A. millefolium, A. pachycephalla, A. aucherii, and A. kellalensis. Ascorbic acid is an antioxidant that scavenges the reactive oxygen species produced under abiotic stresses [52]. Ascorbic acid concentration was improved to cope with drought-induced constraints. The highest level of ascorbic acid was observed in C. arenarius from both ecotypic sites (Figure 3). This increase in ascorbate relates to improving the anti-oxidative defense mechanism in both forage species. Ascorbate is also involved in the dismutase of $\mathrm{H}_{2} \mathrm{O}_{2}$ to water and oxygen [53-56]. Glycinebetaine is a stress-responsive osmolyte. Under exposed drought stress, concentrations of GB increase to protect the cell moisture contents [57]. These organic molecules protect plants from harm induced by oxidative stress [58]. GB is produced in high levels as a first defense against low water conditions to maintain its turgor and cope with oxidative damage [59]. Results of our studies showed that water stress significantly $(p \leq 0.001)$ improves the glycinebetaine contents of both halophytic species. Ecotypic variation of both areas also significantly improves GB contents. It was also observed that $C$. ciliaris improved maximum GB contents more than the other (Figure 3).

When plants were exposed to drought stress, reactive oxygen species started damaging membranes and inducing lipid peroxidation [60-62]. MDA is a product of lipid peroxidation and an indicator of stress level [12,63-65]. It was studied in the roots and 
shoots of Macrotyloma uniflorum; under drought stress, lipid peroxidation increased, and thus the level of MDA also increased [66]. Malondialdehyde is an indicator of lipid peroxidation under drought; therefore, it was observed through data analysis that MDA contents increased under drought stress in both grass species (Figure 3). It was observed from Figure 3 that $C$. arenarius showed high levels of MDA, which is an indicator of more lipid peroxidation in membranes of this species.

Proline is an organic osmolyte that acts as a first plant defense against water stress $[9,67]$. It helps to maintain cytoplasm water potential for the normal functioning of enzymes $[68,69]$. Proline accumulation under drought stress protects cells from membrane damage, water balance, maintenance of enzyme activities, and reactive species scavenging [27,70]. In accordance with previous reports, our results also suggest that proline contents improve significantly in both halophytic species at $60 \%$ field capacity. Ecotypic variation also resulted in significant changes to proline contents in response to detrimental effects of drought. It can be inferred from Figure 3 that $C$. arenarius of the Salt Range accumulated maximum proline contents as compared to $C$. ciliaris. Generally, proline accumulation is an indicator of leaf dehydration and stress susceptibility [71]. Drought stress also improved proline contents in chickpea cultivars [72].

Under stress conditions, plants are deprived of energy and energy-producing molecules due to the malfunctioning of photosynthetic apparatus [73]. High levels of soluble sugars were reported in maize under stress [74]. Starch is degraded to soluble sugars under stressful conditions, inducing a rise in the level of soluble sugars [75]. Similarly, in accordance with previous reports, our results describe a level of total soluble sugars which was also improved significantly under water stress conditions. Both halophytic species improved their total soluble sugar contents under drought stress for stress tolerance (Figure 3). One more study suggested and confirmed the above results that soluble sugars were increased in Haloxylon aphyllum under drought stress [76].

Plants respond to stress by producing $\mathrm{ABA}$, closing the stomata, and producing hydrogen peroxide $\left(\mathrm{H}_{2} \mathrm{O}_{2}\right)$ as a secondary messenger for triggering a cascade of reactions to respond to drought stress, such as in wheat [5]. Drought stress induces the production of organic molecules along with $\mathrm{H}_{2} \mathrm{O}_{2}$ production in cotton [77]. One other study showed that when drought stress was increased to higher levels, it raised the rate of hydrogen peroxide concentration in Poplar species [78]. In the current experiment, it was also observed that hydrogen peroxide contents were increased under drought stress. It was also observed from Figure 4 that both halophytic species showed elevated levels of $\mathrm{H}_{2} \mathrm{O}_{2}$ under waterdeficit conditions. Cotton responds to drought stress by increasing total soluble protein contents under oxidative damage [77]. It was studied that cassava plant improved total soluble proteins under water stress [79]. In agreement with the above results, findings of the present study showed that drought stress significantly improved the total soluble protein contents in both species of grasses.

Oxidative stress was induced in plants by the production of ROS under prolonged drought stress. Superoxides, free radicals, and anions were produced, which interact with the plasma membrane and cause lipid peroxidation by degrading the membranes and diminishing the integrity of cells $[80,81]$. The activities of catalase, superoxide dismutase, ascorbate peroxidase, glutathione reductase, and peroxidase enzymes were up-regulated under drought stress to cope with reactive oxygen species [52]. The enzymatic defense system was also improved for stress tolerance. The current study showed that the activity of the catalase enzyme was improved under drought stress in both species of halophytes (Figure 4). The activity of superoxide dismutase was also increased and helped plants to cope with detrimental radicals produced under stress conditions. High activity of SOD enzymes was observed in C. arenarius of Faisalabad region and C. ciliaris of the Salt Range (Figure 4). The activity of peroxidase enzyme was improved significantly under waterdeficit conditions. It was also observed that $C$. arenarius of the Salt Range showed the maximum activity of POD enzymes under drought stress (Figure 4). In quinoa, activity of 
the POD enzyme increased and was involved in the scavenging of superoxides and toxic oxygen species under stress condition in quinoa cultivars [82,83].

It was studied in Atriplex halimus that water stress increased $\mathrm{Na}^{+}$concentration. The concentration of $\mathrm{Na}^{+}$is an integral part of stress response for the adaptation [84]. It is also known that the concentrations of $\mathrm{Na}^{+}$and $\mathrm{K}^{+}$are competitive with each other. Under drought stress, the sodium level rises, having more affinity for absorption as compared to $\mathrm{K}^{+}$[47]. It was studied from our experiment that the concentration of $\mathrm{Na}^{+}$increased while the concentrations of $\mathrm{K}^{+}$and $\mathrm{Ca}^{2+}$ decreased in roots and leaves under drought stress. This increase might be an adaptation for osmotic adjustment, which implies an accumulation of solutes in plant cells of forage grasses. It was also studied that drought stress not only limits the concentration of $\mathrm{Ca}^{2+}$, but also limits the translocation of these ions from roots to shoots [85].

\section{Conclusions}

The results from this study illustrated that significant drought stress impacts plant growth and biomass and induces oxidative stress. It was concluded from the present study that Cenchrus ciliaris is more resistant to drought in biomass production collected from the Salt Range as compared to Cyperus arenarius. The results showed that $C$. ciliaris can be used as a forage grass under drought conditions as compared to $C$. arenarius.

Author Contributions: Conceptualization, M.A.G.; Data curation, M.A.G., J.W. and L.W.; Formal analysis, M.A.G., J.W. and L.W.; Funding acquisition, M.H.S., L.W. and M.N.A.; Investigation, N.A.A.; Methodology, N.A.A.; Project administration, M.N.A.; Resources, N.A.A.; Software, M.H.S. and M.N.A.; Supervision, N.A.A.; Visualization, J.W.; Writing—original draft, M.A.G., M.H.S., L.W. and M.N.A.; Writing-review and editing, M.H.S. All authors have read and agreed to the published version of the manuscript.

Funding: The authors would like to extend their sincere appreciation to the Deanship of Scientific Research at King Saud University for supporting this research group No. (RGP-199).

Institutional Review Board Statement: Not applicable.

Informed Consent Statement: Not applicable.

Data Availability Statement: Not applicable.

Acknowledgments: The authors highly acknowledge the Government College University Faisalabad, Pakistan, for their support. The authors would like to extend their sincere appreciation to the Deanship of Scientific Research at King Saud University for supporting this research group No. (RGP-199). The authors highly acknowledge the Pakistan Science Foundation, Islamabad, Pakistan for providing funding under the project \#. PSF-MSRT/Bio/P-GCUF (04).

Conflicts of Interest: The authors declare no conflict of interest.

\section{References}

1. Zaheer, I.E.; Ali, S.; Saleem, M.H.; Ali, M.; Riaz, M.; Javed, S.; Sehar, A.; Abbas, Z.; Rizwan, M.; El-Sheikh, M.A.; et al. Interactive role of zinc and iron lysine on Spinacia oleracea L. growth, photosynthesis and antioxidant capacity irrigated with tannery wastewater. Physiol. Mol. Biol. Plants 2020, 26, 2435-2452. [CrossRef] [PubMed]

2. Staniak, M.; Kocoń, A. Forage grasses under drought stress in conditions of Poland. Acta Physiol. Plant. 2015, 37, 1-10. [CrossRef]

3. Bashir, T.; Naz, S.; Bano, A. Plant growth promoting rhizobacteria in combination with plant growth regulators attenuate the effect of drought stress. Pak. J. Bot. 2019, 52, 783-792. [CrossRef]

4. Mohamed, I.A.A.; Shalby, N.; El-Badri, A.M.A.; Saleem, M.H.; Khan, M.N.; Nawaz, M.A.; Qin, M.; Agami, R.A.; Kuai, J.; Wang, B.; et al. Stomata and Xylem Vessels Traits Improved by Melatonin Application Contribute to Enhancing Salt Tolerance and Fatty Acid Composition of Brassica napus L. Plants. Agronomy 2020, 10, 1186. [CrossRef]

5. Afzal, J.; Saleem, M.H.; Batool, F.; Elyamine, A.M.; Rana, M.S.; Shaheen, A.; El-Esawi, M.A.; Javed, M.T.; Ali, Q.; Ashraf, M.A.; et al. Role of Ferrous Sulfate $\left(\mathrm{FeSO}_{4}\right)$ in Resistance to Cadmium Stress in Two Rice (Oryza sativa L.) Genotypes. Biomolecules 2020, 10, 1693. [CrossRef]

6. Mumtaz, S.; Saleem, M.H.; Hameed, M.; Batool, F.; Parveen, A.; Amjad, S.F.; Mahmood, A.; Arfan, M.; Ahmed, S.; Yasmin, H.; et al. Anatomical adaptations and ionic homeostasis in aquatic halophyte Cyperus laevigatus L. Under high salinities. Saudi J. Biol. Sci. 2021, 28, 2655-2666. [CrossRef] 
7. Yaseen, R.; Aziz, O.; Saleem, M.; Riaz, M.; Zafar-Ul-Hye, M.; Rehman, M.; Ali, S.; Rizwan, M.; Alyemeni, M.N.; El-Serehy, H.; et al. Ameliorating the Drought Stress for Wheat Growth through Application of ACC-Deaminase Containing Rhizobacteria along with Biogas Slurry. Sustainability 2020, 12, 6022. [CrossRef]

8. Alam, H.; Khattak, J.Z.K.; Ksiksi, T.S.; Saleem, M.H.; Fahad, S.; Sohail, H.; Ali, Q.; Zamin, M.; El-Esawi, M.A.; Saud, S.; et al. Negative impact of long-term exposure of salinity and drought stress on native Tetraena mandavillei L. Physiol. Plant. 2020. [CrossRef]

9. Deng, G.; Yang, M.; Saleem, M.H.; Rehman, M.; Fahad, S.; Yang, Y.; Elshikh, M.S.; Alkahtani, J.; Ali, S.; Khan, S.M. Nitrogen fertilizer ameliorate the remedial capacity of industrial hemp (Cannabis sativa L.) grown in lead contaminated soil. J. Plant Nutr. 2021, 1-9. [CrossRef]

10. Javed, M.T.; Tanwir, K.; Abbas, S.; Saleem, M.H.; Iqbal, R.; Chaudhary, H.J. Chromium retention potential of two contrasting Solanum lycopersicum Mill. cultivars as deciphered by altered $\mathrm{pH}$ dynamics, growth, and organic acid exudation under $\mathrm{Cr}$ stress. Environ. Sci. Pollut. Res. 2021, 1-13. [CrossRef]

11. Saleem, M.H.; Fahad, S.; Adnan, M.; Ali, M.; Rana, M.S.; Kamran, M.; Ali, Q.; Hashem, I.A.; Bhantana, P.; Ali, M.; et al. Foliar application of gibberellic acid endorsed phytoextraction of copper and alleviates oxidative stress in jute (Corchorus capsularis L.) plant grown in highly copper-contaminated soil of China. Environ. Sci. Pollut. Res. 2020, 27, 37121-37133. [CrossRef]

12. Rehman, M.; Fahad, S.; Saleem, M.; Hafeez, M.; Rahman, M.; Liu, F.; Deng, G. Red light optimized physiological traits and enhanced the growth of ramie (Boehmeria nivea L.). Photosynthetica 2020, 58, 922-931. [CrossRef]

13. Saleem, M.H.; Ali, S.; Rehman, M.; Rana, M.S.; Rizwan, M.; Kamran, M.; Imran, M.; Riaz, M.; Soliman, M.H.; Elkelish, A.; et al. Influence of phosphorus on copper phytoextraction via modulating cellular organelles in two jute (Corchorus capsularis L.) varieties grown in a copper mining soil of Hubei Province, China. Chemosphere 2020, 248, 126032. [CrossRef]

14. Hussain, M.I.; Lyra, D.-A.; Farooq, M.; Nikoloudakis, N.; Khalid, N. Salt and drought stresses in safflower: A review. Agron. Sustain. Dev. 2015, 36, 4. [CrossRef]

15. Razzaq, M.; Akram, N.A.; Ashraf, M.; Naz, H.; Al-Qurainy, F. Interactive effect of drought and nitrogen on growth, some key physiological attributes and oxidative defense system in carrot (Daucus carota L.) plants. Sci. Hortic. 2017, 225, 373-379. [CrossRef]

16. Bhantana, P.; Rana, M.S.; Sun, X.-C.; Moussa, M.G.; Saleem, M.H.; Syaifudin, M.; Shah, A.; Poudel, A.; Pun, A.B.; Alam Bhat, M.; et al. Arbuscular mycorrhizal fungi and its major role in plant growth, zinc nutrition, phosphorous regulation and phytoremediation. Symbiosis 2021, 84, 19-37. [CrossRef]

17. Khan, M.N.; Zhang, J.; Luo, T.; Liu, J.; Rizwan, M.; Fahad, S.; Xu, Z.; Hu, L. Seed priming with melatonin coping drought stress in rapeseed by regulating reactive oxygen species detoxification: Antioxidant defense system, osmotic adjustment, stomatal traits and chloroplast ultrastructure perseveration. Ind. Crop. Prod. 2019, 140, 111597. [CrossRef]

18. Saleem, M.H.; Ali, S.; Rehman, M.; Hasanuzzaman, M.; Rizwan, M.; Irshad, S.; Shafiq, F.; Iqbal, M.; Alharbi, B.M.; Alnusaire, T.S.; et al. Jute: A Potential Candidate for Phytoremediation of Metals-A Review. Plants 2020, 9, 258. [CrossRef]

19. Saleem, M.H.; Ali, S.; Hussain, S.; Kamran, M.; Chattha, M.S.; Ahmad, S.; Aqeel, M.; Rizwan, M.; Aljarba, N.H.; Alkahtani, S.; et al. Flax (Linum usitatissimum L.): A Potential Candidate for Phytoremediation? Biological and Economical Points of View. Plants 2020, 9, 496. [CrossRef]

20. Zhang, Y.; Wang, X.; Ji, H. Co-remediation of Pb Contaminated Soils by Heat Modified Sawdust and Festuca arundinacea. Sci. Rep. 2020, 10, 4663. [CrossRef]

21. Kosar, F.; Akram, N.A.; Ashraf, M.; Ahmad, A.; Alyemeni, M.N.; Ahmad, P. Impact of exogenously applied trehalose on leaf biochemistry, achene yield and oil composition of sunflower under drought stress. Physiol. Plant. 2020. [CrossRef] [PubMed]

22. Hanslin, H.M.; Bischoff, A.; Hovstad, K.A. Root growth plasticity to drought in seedlings of perennial grasses. Plant Soil 2019, 440, 551-568. [CrossRef]

23. Moore, N.A.; Camac, J.S.; Morgan, J.W. Effects of drought and fire on resprouting capacity of 52 temperate Australian perennial native grasses. New Phytol. 2018, 221, 1424-1433. [CrossRef] [PubMed]

24. Brown, G.; Mies, B.A. Ecology and Adaptive Strategies. In Vegetation Ecology of Socotra; Springer: Berlin/Heidelberg, Germany, 2012; pp. 93-139.

25. Chaudhry, A.; Haider, M.; Ahsan, J.; Fazal, S. Determining carrying capacity of untreated and treated areas of Mari Reserve Forest (Pothwar tract) after reseeding with Cenchrus ciliaris. J. Anim. Plant Sci. 2010, 20, 103-106.

26. Naseer, I.; Bajpai, A.; Mishra, A.; Sharif, D.; Roberts, E.; Kushwaha, M. Adjustments in the mechanisms (both at physiological and molecular level) of salt tolerant plants under salt stress. Int. J. Chem. Biol. Sci. 2014, 2, 1-15.

27. Akram, N.A.; Shahbaz, M.; Ashraf, M. Relationship of photosynthetic capacity and proline accumulation with the growth of differently adapted populations of two potential grasses (Cynodon dactylon (L.) Pers. and Cenchrus ciliaris L.) to drought stress. Pak. J. Bot. 2007, 39, 777-786.

28. Arnon, D.I. Copper Enzymes in Isolated Chloroplasts. Polyphenoloxidase in Beta vulgaris. Plant Physiol. 1949, 24, 1-15. [CrossRef]

29. Mukherjee, S.P.; Choudhuri, M.A. Implications of water stress-induced changes in the levels of endogenous ascorbic acid and hydrogen peroxide in Vigna seedlings. Physiol. Plant. 1983, 58, 166-170. [CrossRef]

30. Grieve, C.M.; Grattan, S.R. Rapid assay for determination of water soluble quaternary ammonium compounds. Plant Soil 1983, 70, 303-307. [CrossRef]

31. Bates, L.S.; Waldren, R.P.; Teare, I.D. Rapid determination of free proline for water-stress studies. Plant Soil 1973, 39, 205-207. [CrossRef] 
32. Cakmak, I.; Horst, W.J. Effect of aluminium on lipid peroxidation, superoxide dismutase, catalase, and peroxidase activities in root tips of soybean (Glycine max). Physiol. Plant. 1991, 83, 463-468. [CrossRef]

33. Julkunen-Tiitto, R. Phenolic constituents in the leaves of northern willows: Methods for the analysis of certain phenolics. J. Agric. Food Chem. 1985, 33, 213-217. [CrossRef]

34. Bradford, M.M. A rapid and sensitive method for the quantitation of microgram quantities of protein utilizing the principle of protein-dye binding. Anal. Biochem. 1976, 72, 248-254. [CrossRef]

35. Yemm, E.W.; Willis, A.J. The estimation of carbohydrates in plant extracts by anthrone. Biochem. J. 1954, 57, 508-514. [CrossRef]

36. Velikova, V.; Yordanov, I.; Edreva, A. Oxidative stress and some antioxidant systems in acid rain-treated bean plants: Protective role of exogenous polyamines. Plant Sci. 2000, 151, 59-66. [CrossRef]

37. Giannapolitis, C.; Ries, S. Superoxide dismutase. I. Occurrence in higher plants. Plant Physiol. 1977, 59, 309-314. [CrossRef] [PubMed]

38. Chance, B.; Maehly, A. [136] Assay of catalases and peroxidases. Methods Enzym. 1955, 2, 764-775. [CrossRef]

39. Wolf, B. An improved universal extracting solution and its use for diagnosing soil fertility. Commun. Soil Sci. Plant Anal. 1982, 13, 1005-1033. [CrossRef]

40. Koch, G.G.; Amara, I.A.; Davis, G.W.; Gillings, D.B. A Review of Some Statistical Methods for Covariance Analysis of Categorical Data. Biometrics 1982, 38, 563. [CrossRef]

41. Anjum, S.A.; Ashraf, U.; Tanveer, M.; Khan, I.; Hussain, S.; Zohaib, A.; Abbas, F.; Saleem, M.F.; Wang, L. Drought tolerance in three maize cultivars is related to differential osmolyte accumulation, antioxidant defense system, and oxidative damage. Front. Plant Sci. 2017, 8, 69.

42. Khan, I.; Awan, S.A.; Ikram, R.; Rizwan, M.; Akhtar, N.; Yasmin, H.; Sayyed, R.Z.; Ali, S.; Ilyas, N. Effects of 24-epibrassinolide on plant growth, antioxidants defense system, and endogenous hormones in two wheat varieties under drought stress. Physiol. Plant. 2020. [CrossRef] [PubMed]

43. Hassan, A.; Amjad, S.F.; Saleem, M.H.; Yasmin, H.; Imran, M.; Riaz, M.; Ali, Q.; Joyia, F.A.; Ahmed, S.; Ali, S.; et al. Foliar application of ascorbic acid enhances salinity stress tolerance in barley (Hordeum vulgare L.) through modulation of morphophysio-biochemical attributes, ions uptake, osmo-protectants and stress response genes expression. Saudi J. Biol. Sci. 2021. [CrossRef]

44. Khan, M.N.; Zhang, J.; Luo, T.; Liu, J.; Ni, F.; Rizwan, M.; Fahad, S.; Hu, L. Morpho-physiological and biochemical responses of tolerant and sensitive rapeseed cultivars to drought stress during early seedling growth stage. Acta Physiol. Plant. 2019, 41, 25. [CrossRef]

45. Salama, F.; El-Ghani, M.A.; El-Tayeh, N.; Amro, A.; Abdrabbu, H. Weed flora of common crops in desert reclaimed arable lands of southern Egypt. Taeckholmia 2016, 36, 58-76. [CrossRef]

46. Yadav, S.S.; Kumar, J.; Yadav, S.K.; Singh, S.; Yadav, V.S.; Turner, N.C.; Redden, R. Evaluation of Helicoverpa and drought resistance in desi and kabuli chickpea. Plant Genet. Resour. 2006, 4, 198-203. [CrossRef]

47. Aslam, M.; Ibni Zamir, M.S.; Afzal, I.; Yaseen, M. Morphological and physiological response of maize hybrids to potassium application under drought stress. J. Agric. Res. 2013, 51, 443-454.

48. Hussain, M.; Farooq, S.; Hasan, W.; Ul-Allah, S.; Tanveer, M.; Farooq, M.; Nawaz, A. Drought stress in sunflower: Physiological effects and its management through breeding and agronomic alternatives. Agric. Water Manag. 2018, 201, 152-166. [CrossRef]

49. Faseela, P.; Sinisha, A.K.; Brestic, M.; Puthur, J. Special issue in honour of Prof. Reto J. Strasser-Chlorophyll a fluorescence parameters as indicators of a particular abiotic stress in rice. Photosynthesis 2020, 58, 293-300. [CrossRef]

50. Gharibi, H.; Entwistle, M.R.; Ha, S.; Gonzalez, M.; Brown, P.; Schweizer, D.; Cisneros, R. Ozone pollution and asthma emergency department visits in the Central Valley, California, USA, during June to September of 2015: A time-stratified case-crossover analysis. J. Asthma 2018, 56, 1037-1048. [CrossRef]

51. Sakr, M.; El-Metwally, M. Alleviation of the harmful effects of soil salt stress on growth, yield and endogenous antioxidant content of wheat plant by application of antioxidants. Pak. J. Biol. Sci. 2009, 12, 624-630. [CrossRef]

52. Javed, M.T.; Saleem, M.H.; Aslam, S.; Rehman, M.; Iqbal, N.; Begum, R.; Ali, S.; Alsahli, A.A.; Alyemeni, M.N.; Wijaya, L. Elucidating silicon-mediated distinct morpho-physio-biochemical attributes and organic acid exudation patterns of cadmium stressed Ajwain (Trachyspermum ammi L.). Plant Physiol. Biochem. 2020, 157, 23-37. [CrossRef]

53. Ali, M.; Kamran, M.; Abbasi, G.H.; Saleem, M.H.; Ahmad, S.; Parveen, A.; Malik, Z.; Afzal, S.; Ahmar, S.; Dawar, K.M.; et al. Melatonin-Induced Salinity Tolerance by Ameliorating Osmotic and Oxidative Stress in the Seedlings of Two Tomato (Solanum lycopersicum L.) Cultivars. J. Plant Growth Regul. 2020, 2020, 1-13. [CrossRef]

54. Kamran, M.; Parveen, A.; Ahmar, S.; Malik, Z.; Hussain, S.; Chattha, M.S.; Saleem, M.H.; Adil, M.; Heidari, P.; Chen, J.-T. An Overview of Hazardous Impacts of Soil Salinity in Crops, Tolerance Mechanisms, and Amelioration through Selenium Supplementation. Int. J. Mol. Sci. 2020, 21, 148. [CrossRef]

55. Ahmad, P.; Jaleel, C.A.; Salem, M.A.; Nabi, G.; Sharma, S. Roles of enzymatic and nonenzymatic antioxidants in plants during abiotic stress. Crit. Rev. Biotechnol. 2010, 30, 161-175. [CrossRef]

56. Imran, M.; Hussain, S.; El-Esawi, M.A.; Rana, M.S.; Saleem, M.H.; Riaz, M.; Ashraf, U.; Potcho, M.P.; Duan, M.; Rajput, I.A.; et al. Molybdenum Supply Alleviates the Cadmium Toxicity in Fragrant Rice by Modulating Oxidative Stress and Antioxidant Gene Expression. Biomolecules 2020, 10, 1582. [CrossRef] 
57. Nazar, Z.; Akram, N.; Saleem, M.; Ashraf, M.; Ahmed, S.; Ali, S.; Alsahli, A.A.; Alyemeni, M. Glycinebetaine-Induced Alteration in Gaseous Exchange Capacity and Osmoprotective Phenomena in Safflower (Carthamus tinctorius L.) under Water Deficit Conditions. Sustainability 2020, 12, 10649. [CrossRef]

58. Raza, M.; Saleem, M.; Shah, G.; Khan, I.; Raza, A. Exogenous application of glycinebetaine and potassium for improving water relations and grain yield of wheat under drought. J. Soil Sci. Plant Nutr. 2014, 14, 348-364. [CrossRef]

59. Ma, X.L.; Wang, Y.J.; Xie, S.L.; Wang, C.; Wang, W. Glycinebetaine application ameliorates negative effects of drought stress in tobacco. Russ. J. Plant Physiol. 2007, 54, 472-479. [CrossRef]

60. Saleem, M.H.; Rehman, M.; Zahid, M.; Imran, M.; Xiang, W.; Liu, L. Morphological changes and antioxidative capacity of jute (Corchorus capsularis, Malvaceae) under different color light-emitting diodes. Braz. J. Bot. 2019, 42, 581-590. [CrossRef]

61. Kamran, M.; Danish, M.; Saleem, M.H.; Malik, Z.; Parveen, A.; Abbasi, G.H.; Jamil, M.; Ali, S.; Afzal, S.; Riaz, M.; et al. Application of abscisic acid and 6-benzylaminopurine modulated morpho-physiological and antioxidative defense responses of tomato (Solanum lycopersicum L.) by minimizing cobalt uptake. Chemosphere 2021, 263, 128169. [CrossRef]

62. Nxele, X.; Klein, A.; Ndimba, B. Drought and salinity stress alters ROS accumulation, water retention, and osmolyte content in sorghum plants. S. Afr. J. Bot. 2017, 108, 261-266. [CrossRef]

63. Saleem, M.H.; Ali, S.; Rehman, M.; Rizwan, M.; Kamran, M.; Mohamed, I.A.; Khan, Z.; Bamagoos, A.A.; Alharby, H.F.; Hakeem, K.R.; et al. Individual and combined application of EDTA and citric acid assisted phytoextraction of copper using jute (Corchorus capsularis L.) seedlings. Environ. Technol. Innov. 2020, 19, 100895. [CrossRef]

64. Zaheer, I.E.; Ali, S.; Saleem, M.H.; Noor, I.; El-Esawi, M.A.; Hayat, K.; Rizwan, M.; Abbas, Z.; El-Sheikh, M.A.; Alyemeni, M.N.; et al. Iron-Lysine Mediated Alleviation of Chromium Toxicity in Spinach (Spinacia oleracea L.) Plants in Relation to Morpho-Physiological Traits and Iron Uptake When Irrigated with Tannery Wastewater. Sustainability 2020, 12, 6690. [CrossRef]

65. Imran, M.; Sun, X.; Hussain, S.; Rana, M.S.; Saleem, M.H.; Riaz, M.; Tang, X.; Khan, I.; Hu, C. Molybdenum supply increases root system growth of winter wheat by enhancing nitric oxide accumulation and expression of NRT genes. Plant Soil 2021, 459, 235-248. [CrossRef]

66. Guo, Y.Y.; Yu, H.Y.; Yang, M.M.; Kong, D.S.; Zhang, Y.J. Effect of Drought Stress on Lipid Peroxidation, Osmotic Adjustment and Antioxidant Enzyme Activity of Leaves and Roots of Lycium ruthenicum Murr. Seedling. Russ. J. Plant Physiol. 2018, 65, 244-250. [CrossRef]

67. Rehman, M.; Liu, L.; Bashir, S.; Saleem, M.H.; Chen, C.; Peng, D.; Siddique, K.H. Influence of rice straw biochar on growth, antioxidant capacity and copper uptake in ramie (Boehmeria nivea L.) grown as forage in aged copper-contaminated soil. Plant Physiol. Biochem. 2019, 138, 121-129. [CrossRef]

68. Saleem, M.H.; Ali, S.; Kamran, M.; Iqbal, N.; Azeem, M.; Javed, M.T.; Ali, Q.; Haider, M.Z.; Irshad, S.; Rizwan, M.; et al. Ethylenediaminetetraacetic Acid (EDTA) Mitigates the Toxic Effect of Excessive Copper Concentrations on Growth, Gaseous Exchange and Chloroplast Ultrastructure of Corchorus capsularis L. and Improves Copper Accumulation Capabilities. Plants 2020, 9, 756. [CrossRef]

69. Ali, Q.; Ahmar, S.; Sohail, M.A.; Kamran, M.; Ali, M.; Saleem, M.H.; Rizwan, M.; Ahmed, A.M.; Mora-Poblete, F.; Júnior, A.T.D.A.; et al. Research advances and applications of biosensing technology for the diagnosis of pathogens in sustainable agriculture. Environ. Sci. Pollut. Res. 2021, 28, 9002-9019. [CrossRef]

70. Sakya, A.T.; Prahasto, D.H. The Application of Phosphorus and Potassium to Increase Drought Tolerance in Pereskia Bleo (Kunt) DC with Proline and Antioxidant Indicators. Proc. IOP Conf. Ser. Earth Environ. Sci. 2020, 423, 012055.

71. Mwadzingeni, L.; Shimelis, H.; Tesfay, S.; Tsilo, T.J. Screening of Bread Wheat Genotypes for Drought Tolerance Using Phenotypic and Proline Analyses. Front. Plant Sci. 2016, 7, 1276. [CrossRef]

72. Mafakheri, A.; Siosemardeh, A.; Bahramnejad, B.; Struik, P.; Sohrabi, Y. Effect of drought stress on yield, proline and chlorophyll contents in three chickpea cultivars. Aust. J. Crop Sci. 2010, 4, 580-585.

73. Shahid, M.; Javed, M.T.; Tanwir, K.; Akram, M.S.; Tazeen, S.K.; Saleem, M.H.; Masood, S.; Mujtaba, S.; Chaudhary, H.J. Plant growth-promoting Bacillus sp. strain SDA-4 confers Cd tolerance by physio-biochemical improvements, better nutrient acquisition and diminished Cd uptake in Spinacia oleracea L. Physiol. Mol. Biol. Plants 2020, 26, 2417-2433. [CrossRef]

74. Mohammadkhani, N.; Heidari, R. Effects of drought stress on soluble proteins in two maize varieties. Turk. J. Biol. 2008, 32, 23-30.

75. Abdul, Q.; Abdul, R.; Muhammad, A.; Matthew, A.J.; Qayyum, A.; Razzaq, A.; Ahmad, M.; Jenks, M.A. Water stress causes differential effects on germination indices, total soluble sugar and proline content in wheat (Triticum aestivum L.) genotypes. Afr. J. Biotechnol. 2011, 10, 14038-14045. [CrossRef]

76. Arabzadeh, N. Physiologic Responses of Haloxylon aphyllum to Consecutive Tensions of Dryness and Study of Their Role in Improving Resistance to Dryness of Vase Twigs. Asian J. Plant Sci. 2011, 11, 28-35. [CrossRef]

77. Hasan, M.-U.; Ma, F.; Islam, F.; Sajid, M.; Prodhan, Z.H.; Li, F.; Shen, H.; Chen, Y.; Wang, X. Comparative Transcriptomic Analysis of Biological Process and Key Pathway in Three Cotton (Gossypium spp.) Species Under Drought Stress. Int. J. Mol. Sci. 2019, 20, 2076. [CrossRef]

78. Yang, Y.; Sornaraj, P.; Borisjuk, N.; Kovalchuk, N.; Haefele, S.M. Transcriptional Network Involved in Drought Response and Adaptation in Cereals. In Abiotic and Biotic Stress in Plants-Recent Advances and Future Perspectives; IntechOpen: London, UK, 2016; pp. 3-29.

79. Shan, Z.; Luo, X.; Wei, M.; Huang, T.; Khan, A.; Zhu, Y. Physiological and proteomic analysis on long-term drought resistance of cassava (Manihot esculenta Crantz). Sci. Rep. 2018, 8, 17982. [CrossRef] 
80. Hu, C.-X.; Rana, M.S.; Bhantana, P.; Sun, X.-C.; Imran, M.; Shaaban, M.; Moussa, M.G.; Saleem, M.H.; Elyamine, A.M.; Binyamin, R.; et al. Molybdenum as an Essential Element for Crops: An Overview. Biomed. J. Sci. Tech. Res. 2020, 24, 18535-18547. [CrossRef]

81. Saleem, M.H.; Rehman, M.; Kamran, M.; Afzal, J.; Noushahi, H.A.; Liu, L. Investigating the potential of different jute varieties for phytoremediation of copper-contaminated soil. Environ. Sci. Pollut. Res. 2020, 27, 30367-30377. [CrossRef]

82. Cai, Z.-Q.; Gao, Q. Comparative physiological and biochemical mechanisms of salt tolerance in five contrasting highland quinoa cultivars. BMC Plant Biol. 2020, 20, 70. [CrossRef]

83. Kohli, S.K.; Khanna, K.; Bhardwaj, R.; Allah, E.F.A.; Ahmad, P.; Corpas, F.J. Assessment of Subcellular ROS and NO Metabolism in Higher Plants: Multifunctional Signaling Molecules. Antioxidants 2019, 8, 641. [CrossRef] [PubMed]

84. Gharaibeh, M.A.; Eltaif, N.I.; Albalasmeh, A.A. Reclamation of Highly Calcareous Saline Sodic Soil Using Atriplex Halimus and by-Product Gypsum. Int. J. Phytoremediat. 2011, 13, 873-883. [CrossRef] [PubMed]

85. Hussain, H.A.; Hussain, S.; Khaliq, A.; Ashraf, U.; Anjum, S.A.; Men, S.; Wang, L. Chilling and Drought Stresses in Crop Plants: Implications, Cross Talk, and Potential Management Opportunities. Front. Plant Sci. 2018, 9, 393. [CrossRef] [PubMed] 